years ago, together with Dr. Cunningham, to proceed to India in order to undertake, under the auspices of the Indian Government, a prolonged study of the causation of cholera, especially in regard to its reputed relation to parasitic organisms. At that time little was known or thought about Bacteria, and the public mind had been aroused by Hallier's (now long-exploded) theory of a ricefungus as the cause of cholera, just as more recently it has responded to Dr. Koch's invitation to believe in the comma-bacillus. Dr. Lewis and his companion were authorised to visit Prof. Hallier at Jena and Prof. de Bary (in those days not attached to French Strasburg !) for the purpose of acquainting themselves with methods of mycetological research before proceeding to India. A few weeks was all the time allowed them for this visit, and consequently they took little to India excepting their own conscientious habits of work and that modicum of knowledge of microscopic technique which was considered sufficient for the highest medical qualification in England in those days. Nevertheless these observers made most valuable and minute researches on the microscopic organisms present in the dejecta of cholera-patients, which were published by the Government of India. Dr. Lewis extended his researches into the general question of the presence of microscopic organisms in the blood and tissues of man in health and disease, and was led to some very interesting discoveries. His results were published from time to time by the Government of India, and were re-published as they appeared in the Quarterly Fournal of Microscopical Science.

Dr. Lewis's work was always remarkable for the extreme care with which positive results were asserted, and for the fairness with which the researches of predecessors in the same field were considered and discussed. His most remarkable discovery was that of the little nematoid worm occurring in the blood of persons suffering from a form of chyluria and elephantiasis, to which he gave the name Filaria sanguinis hominis. This discovery was published in 1872 . Some years later Dr. Bancroft discovered in Australia the adult worm from which the brood of minute blood-parasites is derived, and, still later, an unsuccessful attempt has been made by Dr. Patrick Manson to show that the young pass an intermediate stage of existence in the alimentary canal of gnats, which suck them in together with the blood of worm-infested persons.

It is no small thing in these latter days to discover a new human parasitic worm of great pathological significance, and it was in recognition of this discovery, as well as in view of his important contribution to the discussion of "the cholera-bacillus theory," that the Council of the Royal Society in last April selected Dr. Timothy Lewis as one of the fifteen candidates to be submitted to the Society for election in next June.

In regard to the question of the relation of Bacteria to cholera and similar diseases, Dr. Lewis had a vast store of both published and unpublished observation. With characteristic caution and modesty, he had refrained from dogmatising on the subject. Working for twelve years in Calcutta, with daily access to cholera patients, he was thoroughly familiar with the several different forms of Bacteria which are to be found in the alimentary tract and in the dejecta of choleraics. Unlike some of his recent successors in this line of research, Dr. Lewis was also familiar with the different forms of Bacteria which occur in the healthy human mouth and intestines, and in potable waters. He was therefore able to demonstrate. immediately on the publication of Koch's figures of the so-called "comma-bacillus" that this form (asserted by Koch to be peculiar to cholera evacuations) was nothing more nor less than a Spirillum broken by manipulation, and commonly to be found in the mouth of healthy persons. The importance of this contribution to the controversy excited by Dr. Koch's statements cannot be too highly estimated. Its accuracy was uni- versally recognised at once, and has never been called in question. Dr. Klein has since come to the conclusion that not only are organisms of the exact form of Koch's cholera-comma abundant in the healthy saliva, as shown by Lewis, but that some of these forms have precisely the same physiological conditions of growth, and precisely the same action upon gelatine as Koch considered to be characteristic of those obtained from cholera evacuations.

At the time of his death Dr. Lewis was carrying on in his laboratory at Netley an extensive series of culture and inoculation experiments, chiefly upon the Bacteria which occur in the alimentary canal of man.

Those who enjoyed his personal friendship valued Dr. Lewis for his warm-heartedness no less than for the rare combination of enthusiasm with caution in his work which gives his published results a very special value. It is perhaps some satisfaction to his friends to know that he had heard of the recognition of his merits by the Royal Society Council before the commencement of the attack of inflammation of the lungs which so rapidly ran to a fatal termination.

E, R. L.

\section{A SKETCH OF THE FLORA OF SOUTH AFRICA}

UNDER this title we would draw the attention of botanists to a very able essay on the botanical regions of South Africa, contributed to the "Official Hand-Book of the Cape of Good Hope" for 1886, by Harry Bolus, F.L.S., an accomplished botanist, who has devoted many years to the investigation of South African plants.

That extra-tropical South Africa is one of the most varied botanical regions on the globe is a fact familiar to both botanists and gardeners, from the days of Linnæus,who epitomised its richness in the expression, "Ex Africâ semper aliquid novi,"-and of the earliest cultivators of greenhouse plants, who were indebted to the Cape of Good Hope, far more than to any other regions of the globe, for what were, and till Japan and Australia eclipsed it, the prime favourites of the conservatory. There are those still alive who can remember the time when planthouses were ornamented with little else than Cape Heaths, Pelargoniums (miscalled Geraniums), Polygalas, Proteas, Oxalis', Mesembryanthemums, Everlastings, Stapelias, Irideæ, and Cape bulbs innumerable, and when the illustrated horticultural serials of the day were either devoted to these, or contained figures of more of the plants of this than of any one other country: It is true that the cultivation or all but a very few of the heaths and geraniums has been abandoned for things of not greater beauty, and of far less interest, but this is due, not to want of appreciation, but in the case of some to their not being amenable to the treatment of the "soft-wooded" plants now in vogue, and of others to the fact that their flowering period - of the bulbs especially-is a very brief one, and that the flowers soon fade when cut.

To return to the little essay before us: the attempt to define the South African regions of vegetation is not a new one; it had been essayed by Meyer and Drège, Zeyher, Griesebach, and others, but not successfully; and the author of the sketch under consideration is the first who has succeeded in presenting satisfactorily the salient botanical characters of that flora, as affected by, or in correspondence with, geographical and other physical conditions; whilst he alone has given such vivid pictures of the vegetation of the different botanical regions he has defined, that any one with even an elementary knowledge of South African plants can fancy himself travelling over the ground.

The two dominant features of the South African flora are, the number of orders, genera, and species that it contains, and the limitation of great groups of these 
within very narrow and well-defined areas. There are five of these areas, differing from one another in the aspect as well as in the composition of their floras more decisively than do any other five contiguous areas of similarly small extent on the surface of the globe. These five together have been estimated to contain the extraordinary number of 14,000 species of flowering plants! which are comprised under 200 natural orders (nearly three-fourths of the known orders of plants), and 1255 genera (one-sixth of the described genera of the whole world). Though possessing no truly Alpine region, it is by far the richest extra-tropical area on the globe in respect of genera and species, and is probably not surpassed by any tropical area of equal extent ; a circumstance which may be taken together with the fact, that the vast proportion of the species are low herbs or small shrubs - trees being very rare both in species and individuals, and that there is not a single arboreous genus of more than a very few species. There is no dominant genus of trees like the Eucalypti of Australia and the Conifers of northern regions, or even the oaks or beeches of Europe, that monopolise great areas and determine the absence or presence of a multitude of plants of lower stature. The following are Mr. Bolus's regions :-

(I) The South-Western Region.-This (which might be called the Cape proper region) extends in a curve from near the mouth of Olifant's River along the coast facing the Western Atlantic, round by the Cape of Good Hope to Cape Agulhas, and thence to near Port Elizabeth along the coast facing the Southern Atlantic. Throughout its length-about 600 miles-it maintains a breadth of between 40 and 80 miles, never more or less, and is bounded on its landward sides by mountain-ranges attaining 4000 to nearly 8000 feet in elevation-of which the eastern run east and west, the western north and south. The surface is varied with bushy, grassy, sandy, and rocky tracts, of which some appear desolate from a distance, but on examination are found to swarm with genera and species. It is a region of small-leaved herbs and bushes - of Irideæ, Orchideæ, Rutaceæ, Ericeæ, Restiaceæ, Compositæ, Proteaceæ, Polygaleæ, Mesembryanthemums, Oxalideæ, Geraniaceæ, and Leguminosæ. It is that whence all the Cape plants of the greenhouses of the last generation were derived. The climate is dry, temperate, and comparatively equable, with a winter rainfall which varies excessively from 24 inches at Cape Town to 60 in some of its own suburbs, but everywhere rapidly diminishing with distance from the coast and from the vicinity of Cape Town. The few forests are near the few rivers, and their trees rarely exceed 50 feet in height. As an instance of the endemic nature of its vegetation, the genus Erica forms one of the many conspicuous examples. It contains no fewer than 300 Cape species; all, or nearly all, are confined to this region, and various other genera contain upwards of roo endemic species. The total number of flowering plants in this region is about 4500 . No temperate area of the globe of its extent is nearly so peculiar or rich. California offers but a faint counterpart; and the restriction of the majority of the species of Cistus and Ulex to the Atlantic coasts of Europe offers an even fainter example of restricted distribution.

(2) The Tropical African Region (which might be called the Natal region).--Unlike the western temperate coast, the vegetation of the eastern temperate retains the characteristic features of that of tropical Africa. From Port Elizabeth northwards to Abyssinia there is no sharp delimitation of floras. This region is bounded on the east and south-east by the Atlantic, and stretches inland for from 60 to 100 miles to ranges of mountains of 5000 to 10,000 feet high, which bound it on the west. The surface is varied with bush and park, which, proceeding northward, give place here and there to extensive forests, and it is traversed by many streams. The herbage, and bush- and tree-foliage, are greener than in the south-western district, and the foliage larger. The rains are summer ones, the temperature rather higher than in the west, and much more so to the north. Though there is some overlapping of the vegetations of this and the Cape region proper in the neighbourhood of Port Elizabeth and Grahamstown, the tranșition from one to the other is wonderfully sudden. The 300 heaths may be said to disappear bodily, as do the Cape Rutaceæ, Proteaceæ, and Orchideæ. As suddenly appear giant Cycadeæ, Aloes, leafless succulent tree Euphorbias, with different tribes of Orchideæ, Leguminosæ, and Amaryllideæ, often grouped in striking assemblages of grotesque forms, whilst a palm, Phonix reclinata, reaches lat. $33^{\circ} \mathrm{S}$. Along with African types, Indian abound, both in genera and species, especially to the northward.

(3) The Karroo Region.--Returning now to the Western Atlantic coast of South Africa, from Olifant's River to the Orange River, and thence south-eastwards, bounding the Cape proper region on the north, extends a vast shallow basin about 2000 feet above the sea-level, except towards its western or littoral boundary. It forms a curve somewhat concentric with that of the Cape region proper, and extends a little further east into the tropical African region. It is about 700 miles in length, and from 30 to 70 in breadth from the bounding mountains on the north, which are the Nieuveld Bergen, to lower ranges on the south. The surface consists of sandy, stony, or fertile plains of vast extent, traversed by river-beds, and by the courses of torrents filled by summer thunderstorms, but dry in winter. Permanent water is scarce, and (as in California) sheep have denuded large areas of native vegetation. The climate is excessive ; the rainfall, chiefly a summer one, from 7 to 14 inches according to locality. During the dry season the country is a desert, but after a shower it is suddenly, but transiently, transformed into a vividly-coloured garden.

"I was amazed on visiting that desert country, after the rains of June to July $\mathrm{I} 883$, to see tracts, hundreds of acres in extent, covered with sheets of living fire or glowing purple, visible from several miles' distance, caused by the beautiful Compositæ in flower; and nothing is more curious than to see this luxuriance intermingled with the black or white branches of dead shrubs killed by previous druughts, standing like ghostly intruders on a scene of merriment and joy. These charming scenes pass away all too rapidly, and in a month or two little that is beautiful remains."

The only tree is the ghastly Acacia horrida, fringing the dry river-beds. Of the Orders of the Cape region proper, Ericeæ, Restiaceæ, Polygaleæ, Orchideæ, Proteaceæ, Rutaceæ, almost all are absent, and a variety of socalled succulent plants appear, especially innumerable species of Mesembryanthemum, together with Portulaceæ, Zygophylleæ, Crassulaceæ, Stapelias, Ficoideæ, and dwarf Euphorbias, besides which many other genera that are never succulent elsewhere, here have species with fleshy roots, stems, or leaves. The tree Aloes of the Eastern region are fairly well represented, but by different species, and the same remark applies to the Geraniaceæ of the Cape region. The curious Elephant's-foot (Testudinaria) is a characteristic plant, as are the two species of the parasitical Rafflesiaceous genus Hydnora, which extends to Abyssinia.

(4) A very singular region or subdivision of the Karroo region is called by Mr. Bolus the "Upper Karroo," or "region of Composite," which occupies an inland broad area north of the Karroo region, everywhere distant from the coast, about 400 miles from east to west, and 150 to 200 miles in breadth. It is a mountainous country, only partially explored, and supposed to have a mean elevation of 4000 to 5000 feet. Its prevalent features are that of a treeless, heathy tract, or dry elevated moorland, covered with shrublets of a dull hue. The climate is severe, the summer nights are always cool, sharp frosts are common, 
and snows falls in winter. Compositæ abound. Of nearly 1000 species that have been collected in this region, $6 \mathrm{I}$ genera and $23 \mathrm{I}$ species are referable to this Order. Of Orchids only four species have been found Rutaceæ, Ericaceæ, and Restiaceæ are all but absent, and Proteaceæ wholly so.

(5) The Kalahari Region is the name Mr. Bolus gives to the vast tract of country north of the Composite region, west of the Natal region, and south of the tropic of Capricorn. It is a desert country, with an extreme climate, a rainfall of summer thunderstorms, hot summers with cool nights, and frosts in winter. Its essential features are of a country clothed with grass in tufts, and isolated shrubs and trees, which form forests in the north, and are thus probably continuous with the forests of tropical Africa. The Cape flora has here disappeared, and with it we take leave of Mr. Bolus's very able and most interesting contribution to botanical geography, regretting that want of space prevents any notice being taken of the many valuable observations and comparisons that he has made relating to the affinities of the South African with the Australian flora, and other matters of scientific interest.

J. D. H.

\section{THE INTERNATIONAL COMMITTEE OF WEIGHTS AND MEASURES}

THE Comité International des Poids et Mesures, which 1 has its bureau at Sèvres, has recently issued its ninth Report to the contracting Governments. The Report gives an account of the work done by the Committee during $\mathbf{1 8 8 5}$, and a statement of the probable expenses of the Committee for the current year. During the last year new instruments for the accurate comparison of standards of the metric system have been obtained at a cost of about 500/., making a total cost of about $7000 l$. for instruments supplied to the Bureau. For the present year the expenses of the Bureau are estimated at 100,000 francs (4000l.), the annual expenditure of the Committee being limited by the Convention to that amount, of which sum about $265 \%$. is for payments to various officers of the Comite. These expenses are divided amongst the twenty contracting Governments, the annual contribution of Great Britain and Ireland amounting to about jool. The new instruments include a comparator for measures of length by $M$. Brunner; new mercurial thermometers by $M$. Tonnelot; an air thermometer by M. Golaz; a spherometer by M. Brunner; and other measuring instruments by MM. Oertling, Boudin, Alvergniat, Simmen, and the Société Genevoise.

In the fourth volume of the Travaux et Miemoires of the Bureau (Paris, Gauthier-Villars, I885) reference was made by the Director of the Bureau to the work then in progress, and in the present Report a summary is given of the whole work done by the Committee during the past twelve months.

The work of the Director has specially included the verification of the lengths and coefficients of expansion of several standard metres, and the determination of the weights and specific gravities of several standard kilogrammes for different Governments and scientific authorities. A report is given on the comparison of the new kilogramme prototype (K. III.) with the old kilogramme des Archives, and also on the verification at Paris, by Dr. J. Broch and Mr. H. J. Chaney, of certain British standards. During the present year the Committee report that Dr. Broch will continue his researches on the influence of light on the defining-lines of standards of length, and M. Benoit will also carry on his experiments on the best means of comparing end-measures of length (mesures à bouts) with line-measures (mesures $a$ traits). Dr. Thiesen will continue his interesting studies on balances and the verification of kilogramme standards.
Dr. Chappuis, with the assistance of Dr. Guillaume, will also continue the experiments on the verification of thermometers:

It wou:d appear that the Committee are carrying out the duties intrusted to them with all possible care and despatch. In the preparation of the alloy of platinumiridium, of which the standards of the kilogramme and metre are made, extraordinary difficulties were originally encountered, owing mainly to the presence in the iridium of iron, rhodium, ruthenium, osmium, and other metals, and the Committee therefore obtained the assistance of MM. Stas and Debray. The report of these eminent metallurgists shows that the Committee are indebted to Mr. G. Matthey for the production of an alloy having the high purity and finish required for such work.

The Report of the Committee includes copies of its correspondence with the different contracting Governments. In an able note to the Japanese Minister, Dr A. Hirsch (the Secretary of the International Committee) explains the objects of the Metric Bureau, and it is gratifying to find that Japan has now joined the Convention. From the correspondence with this country it would appear that our Government will in due course obtain copies of the new metric standards.

The Committee announce that the vacancies caused by the death of Prof. Heer and the resignations of Gen. Wrede and Dr. Gould have been filled by the election by the Committee of Prof. Th. v. Oppolzer, Mr. W. H. M. Christie, and Prof. Thalèn.

The Report also includes copies of a correspondence with reference to a proposal made by the French Government to extend the functions of the Bureau to the determination and verification of electrical standards of resistance and light, for the use of the different Governments. The proposal appears to have gone no farther at present than asking the several contracting Governments whether they would have objection to the preparation of estimates showing the cost of a new or extended Bureau for electrical purposes. The replies of Belgium, Denmark, Spain, the United States, Italy, Servia, and Switzerland are attached, but, excepting Spain and Switzerland, it cannot be said that generally the Governments appear to bave given the proposal the most cordial welcome.

\section{THE WEATHER OF THE ICE SAINTS FESTIVALS OF 1886}

AST year we chronicled (NATURE, vol, xxxii. p. 62) one of the most disastrous snowstorms that ever occurred at this season in Vienna, where, on May I5, there fell $5 \frac{1}{2}$ inches of snow, and the cold accompanying the storm was so intense that several persons who were exposed to it were frozen to death. Over Austria and Hungary snow covered the fields and vineyards, and, the crops being in a somewhat advanced condition at the time, an incalculable amount of damage was done. But the festivals of the Ice Saints (May I i, 12 , and 13 ) this year have been marked off for a wider and deeper remembrance by storms of wind, rain, hail, and snow in all the continents of the northern hemisphere, which, for number and destructiveness, are perhaps unexampled at this time of the year.

In the British Islands the cold acquired its greatest intensity on the five days from May II to 15 , and was coincident with a system of pressures which appeared in the Channel, and thence proceeded in a north-northeasterly direction through the North Sea to the southwest of Norway, which was reached on the I5th. It necessarily resulted from this distribution of pressure that northerly and easterly winds prevailed in these islands, and temperature fell correspondingly low. Over that 